Маја Радонић

Факултет за културу и медије, Београд majar@yandex.ru

https://doi.org/10.18485/ai_san_o_gradu.2019.ch6 821.163.41.09 Црњански М.

\title{
САН О ГРАДУ У ПОЕТСКОМ СВЕТУ МИЛОША ЦРЊАНСКОГ
}

\author{
У тој вароши он ће свој живот \\ као утеху завриити.
}

\begin{abstract}
Тежња ка простору среће, који представља визију идеалног места у даљини, једна је од изразитих одлика поетског света Милоша Црњанског. Док у ранијим делима просторе среће чине етерични, небоземни симболи удаљених отворених простора природе, у поеми Ламент над Београдом и Другој книзи Сеоба, два идеална града у даљини, Београд и Санкт Петерсбург, постају симболи вечне лепоте и трајања, завршно и коначно одредиште трагања за апсолутом. Овај рад се бави вишезначношћу симбола града у ова два позна дела Милоша Црњанског, као и питањем како је песник „Суматре“ своје коначно одредиште нашао у загрљају идеалног града.
\end{abstract}

Кључне речи: Милош Црњански, Ламент над Београдом, Друга книга Сеоба, идеални град.

Књижевни свет који је створио Милош Црњански (1893-1977), можемо назвати поетским светом, мада је он објавио свега једну песничку збирку Лирика Итаке (1919), песму „Суматра“ (1920) и поеме Стражилово (1921), Сербиа (1926) и Ламент над Београдом (1962). 
Већи део његовог стваралаштва чине прозна дела, попут збирке приповедака Приче о мушком (1920), романа Дневник о Чарнојевићу (1921), Сеобе (1929), Друга къига Сеоба (1962) и Роман о Лондону (1971), путописа Писма из Париза (1921), Љубав у Тоскани (1930), мемоарско путописно-романескне прозе Код Хиперборејаияа (1966), мемоарске прозе Ембахаде (1983), бројних есеја, недовршене монографије Микеланђело (1982), уз три драмска дела: Маска (1918), Конак (1958) и Тесла (1966). ${ }^{1}$ Ипак, његов изворни поетски сензибилитет и особена песничка имагинација изградили су кроз целокупно дело Милоша Црњанског јединствени али динамични поетски свет са својим специфичним законитостима, видљивим у сваком тексту који је изашао из његовог пера, било да је тај текст попримио лирски, прозни или драмски облик. Треба свакако нагласити да, иако јединствена у својој поетичности, слика света у делу Милоша Црњанског пролази кроз динамичне промене током деценија у којима писац ствара, у складу са дубином и проницљивошћу његове стваралачке имагинације, која је неретко сеизмолошки прецизно сагледавала и слутила кључне правце ка којима се тај свет и човек у њему крећу и мењају. Истовремено са импулсима који су у Црњанскову слику света долазили из спољашњег света, попут промена места и сталних путовања, као и промена духа времена кроз које је тај свет пролазио, најважнији импулси промена и дина-

1 „Милош Црњански је са истом стваралачком страшћу писао и поезију и прозу, и песме и поеме, и приповетке и романе, и есеје и критике, и поетичке комедије и класичне драме, и краће путописне текстове и дуже путописне целине, али је истовремено знатно проширивао структуралне могућности готово сваког од помињаних књижевних облика и жанрова. Оно се најчешће кретало према међусобном потирању структуралних разлика између појединих књижевних облика.“ (Недић 2011: 263) 
мизам његове уметничке слике света долазили су из унутрашњих промена и неминовног померања фокуса кроз које је личност самог уметника пролазила у свом кретању кроз време и простор. Ова промена фокуса видљива је у промени слике простора среће ка којима теже јунаци Црњанскових романа, као и лирски субјекти његове поезије, који креће од раних суматраистичких етеричних простора и узвишених слика природе у истоименој песми и поеми Стражилово, преко небоземних предела удаљеног рајског царства који симболизује Исаковичева Русија у Сеобама, све до поетске визије града код позног Црњанског, коју представљају слике два идеална (и недостижна) града у даљини као коначног и вечног одредишта, а то су Санкт Петерсбург Павла Исаковича у Другој књизи Сеоба и Београд у Ламенту над Београдом.

Уочено је већ у досадашњим проучавањима да је једна од најизразитијих одлика његовог дела изражен контраст између простора кроз које се крећу јунаци његове прозе, лирски субјекти његових песама, али и сам писац, који су по правилу, простори тескобе, скучености и сивила из којих се снагом имагинације субјект пребацује у просторе светла, ширине, чистоће и свежине. ${ }^{2}$ Стварносни простор у којем затичемо јунаке његовог прозног света или лирске субјекте његових песама по правилу је простор који изазива осећај тескобе код субјекта и истовремену потребу да се простор

2 „Нови свет грађен је као антитетичка слика постојећег света, симетријом апсолутних супротности. Уколико је стварност ружнија, утолико је пројекција простора среће лепша. Уколико су стварности света теже - у буквалном и преносном смислу утолико су елементи срећног пространства лакши. Уколико су боје стварности тмурније, утолико су боје пројекције светлије, хармоничније, опојније.“ (Џаџић 1976: 47) 
среће пронађе снагом имагинације у неспутаним далеким просторима и висинама, које су сушта супротност полазној тачки, простору у коме се он већ налази или кроз који се креће. У једној од познатијих студија о овој теми Простори среће код Црнанског Петра Џаџића, аутор овим термином означава идеализоване удаљене просторе којима теже јунаци Црњанског, полазећи од студије Гастона Башлара Поетика простора, у којој француски теоретичар супротставља срећне просторе просторима непријательства или запрльаним просторима. Тако би стварносни простор у коме затичемо јунаке прозног и(ли) поетског света Милоша Црњанског представљао простор непријательтва, тј. простор тескобе у коме се осећају скучено, бесциљно, спутано, без обзира на то да ли су у питању истински тмурни пејзажи попут магловитих блатњавих равница у Сеобама, или један од уређенијих европских градова као што је изарствујушча Вијена у Другој кюизи Сеоба. За Павла Исаковича, који „није био занет престоницом“ загледан у свој идеални циљ, у Русију, Беч је „варош као варош“ као и цела Аустрија уосталом, која „му је личила на касарну принца Александра, у Белграду, која је имала 360 прозора“ (Црњански 1990: 316). Ocећај тескобе и потреба да се имагинацијом пребаци у идеализовани простор среће ка коме неуморно стреми, ${ }^{3}$ прате га и у Темишвару, одакле преко Будима креће ка Бечу, на самом путу, на успутним одмориштима, на бучним седељкама, у трактиру у коме одседа, и само га визија

3 По Гастону Башлару, имагинација је пре „способност изобличавања слика и обликовања које нам нуди опажење, а понајвише способност ослобађања од првих слика, способност мењања слика“" (Башлар 2001: 5), док ће на другом месту навести: „Уистину, тамо где је имагинација свемоћна, стварност постаје непотребна [...]“ (Башлар 2001: 305). 
Нове Србије и далеког града подигнутог „на леду“ Санкт Петерсбурга који га чека у даљини, воде кроз ове, за њега, стране, једнолично заморне и тескобне просторе непријательства.

Важно је истаћи и да идеални удаљени предели „унутрашње емиграције“ (Ахметагић 2014), у које имагинацијом одлазе јунаци Црњанскове прозе или лирски субјекти у поезији, нису измаштани, нестварни предели, већ постојећи простори и места, попут Росије Вука Исаковича у Сеобама, Београда из Ламента над Београдом, или Санкт Петерсбурга Павла Исаковича у Другој књизи Сеоба, али су сви они далеки и недостижни у тренутку док се о њима сања, док истовремено тежња ка њиховом досезању никада не престаје. ${ }^{4}$ То су коначна одредишта судбине, визија која јунаке Црњанског, попут звезде водиље, води кроз просторе које доживљавају мучним и страним. Без ових имагинативних слика које представљају циљ њихових живота, изгубили би и најмањи осећај смисла и сврхе живота, који им у датим реалним просторима стално измиче. Тако идеализовани простор среће ка којем се креће поворка ликова из поетског света Милоша Црњанског, прераста у симбол трајне, неупитне и вечне лепоте и смисла постојања, у симбол апсолута којем у својој најдубљој суштини тежи свако људско биће.

4 „Још једном, и као журећи се, пре него што опет буде стигао у близину Аранђелову, у своје насеље, у своје бриге, Вук Исакович поче размишљати о Русији. Још увек уверен да ће се одселити са децом и својим слугама тамо, грабио је да овако, несметан, још једном промисли како је то једино што га може спасти од свега тога, неизмерно бедног, ниског и тегобног што га на дому, и идућих година, чека. Отићи некуд и живети безбрижно, одвести и ове људе, да живе негде лако и пријатно, чинило се Вуку Исаковичу тако могуће. Негде је морало бити нешто светло, значајно, па треба отићи тамо.“ (Црњански 1990: 157) 


\section{Градови Милоша Црњанског}

Слика града у књижевности никада није била јединствена и једнозначна - још од два Библијска града из „Откровења Јовановог“, Вавилона „града звери“, симбола свеколиког зла и Новог Јерусалима „божанског града“, симбола свеколиког добра, амбивалентна слика града уочљива је не само кроз различите књижевне епо$\mathrm{xe},{ }^{5}$ него и у појединачним опусима појединих писаца. Тако је, на пример, модерни град својеврсна позорница апокалипсе и тескобе у раним песничким збиркама Миодрага Павловића, док су средњовековни градови Цариград или Смедерево у цилусу песама Велика Скитија, симболи цивилизованости вишег реда, трајности и лепоте, о чему је било речи у тексту „Престоница васељене и град памтивека“6 Тако је и код самог Црњанског - Београд је у Другој књизи Сеоба „аустријска варош“, град као сваки град, нимало различит од безличних градова аустријског царства како их види Павле Исакович, самим

5 У уводу студије Црғански, Мегалополис, Слободан Владушић запажа да „историја идеја бележи различита тумачења града која ће наглашавати поједине аспекте града на рачун других“, наводећи пример Дантеовог „антиурбаног дискурса“ у Божанственој комедији, у којој је град „пре свега модел за пакао“, док се у Утопији Томаса Мора или Кампанелином Граду Сунца, „пројектује идеја идеалног града, који је истовремено простор могућности остварења идеала, али и скровиште пред хаосом који се пружа изван зидина града." (Владушић 2012: 18)

6 „Град је амбивалентан симбол (у поетици Миодрага Павловића) и јавља се у два основна вида: као утврђење, одбрана цивилизације и културе, место хармоничног људског бивања, рекли бисмо парадоксално природно место за човека, и то је слика митског или средњовековног града; други вид је модерни град као позорница Апокалипсе и космичке усамљености појединца, као у његовим првим песничким збиркама 87 песама (1952) и Стуб сећаға (1953), или у поеми Апокалипса или ужа Србија (1986).“ (Радонић 2018: 186-187) 
тим и место тескобе, да би у Ламенту над Београдом израстао у најсветлији симбол његовог песништва, у његов лични поетски Нови Јерусалим. За песника суматраизма и писца Сеоба, град постаје важна тема од његовог боравка у Берлину, како то прецизно уочава Слободан Владушић у студији Црњански Мегалополис, ${ }^{7}$ да би три послератна велика романа Милоша Црњанског тематизовала град као главну позорницу дешавања: Беч у Другој књизи Сеоба, Рим Код Хиперборејаиа и коначно Лондон у Роману о Лондону, а тестаментарна поема, чувени Ламент над Београдом, највећа је поетска посвета српској престоници.

Црњански је писао и о другим великим европским градовима попут Париза, Штокхолма, Берлина, Пеште, Мадрида у својој путописној прози, али град као сан и као визију удаљеног идеализованог простора среће, налазимо само у слици Санкт Петерсбурга у Другој књизи Сеоба и слици Београда у Ламенту над Београдом. Како је Санкт Петерсбург постао сан о граду у великом роману Црњанског? У првој књизи Сеоба, слика далеког идеалног неограниченог простора је Росија Вука Исаковича, која се на крају успиње на небо, у чувени бескрајни плави круг и звезду у њему. Та Росија Вука Исаковича нема јасне контуре ни облике, она је само бескрајно чисто пространство где царује слатко православије и где је све другачије од предела у којима је пролазио његов живот, који су „све оно блато у које је

7 „Ствар постаје занимљивија када се види да у предратном опусу Црњанског доминирају суматраистичке сцене, све до једног момента, а то је сусрет са Берлином (Книга о Немачкој, 1931. год.) односно велеградом у коме ће Црњански уочити напетост између Берлина и Немачке, наслућујући тако прве црте Мегалополиса. Суматраизам може бити одговор на град, али не и на Мегалополис.“ (Владушић 2012: 54) 
требало да се врати, са својим животом лудим и празним и ништавним“, а „Русија му се чињаше као једна велика, непрегледна, зелена пољана, по којој ће јахати“ (Исто: 104, 21). Баш као и лирски субјект „Суматре“ и Стражилова, јунак Сеоба налази простор среће у небоземним пределима, идеализованим срећним просторима нејасних облика и контура, где је све „светло, значајно и лако“ и који се, коначно спајају са бескрајним небеским пространством:

За нечим надземаљским зажуде те ноћи Вук Исакович, не само за себе; већ и за своје, заспавши пред својом колибом, у запари летње ноћи пред Штрасбургом, осетив да је преварен, понижен, а да беше рођен за нешто чисто, светло, ванредно и непролазно, као ти комади неба, што сребрни и плави лебде сву ноћ, испод сјајних сазвежђа. (Црњански 1990: 115)

Три деценије касније, песник је у емиграцији у европском велеграду Лондону, а престоница великог аустријског царства Беч, или царствујушча Вијена, главна је позорница у којој се одиграва лична драма Вуковог потомка Павла Исаковича и његовог национа сербског у Другој књизи Сеоба. Овај пут, простор непријатељства, простор тескобе, бесмисла и спутаности из кога треба отићи што даље, на место које је сушта супротност ономе где се налази јунак романа, јесте цела аустријска царевина коју симболизује њена престоница Вијена: „Кад би, тако, устао, и стајао, у мраку, на свом доксату, изнад Вијене, Исаковичу се чинило да га та варош вуче у дубину, да се стрмоглави, и сурва. На целој тој великој пучини вијенских кровова, није имао никог свога“ (Исто 1990: 210).

Поред тога што Павле Исакович није био опчињен престоницом, која је за њега била варош као варош, налик целој Аустрији, иарствујушча Вијена је место не- 
пријатељства и због тога што представља административни центар царевине, место моћи и одлука које су се тицале свих који су живели под аустријском круном, а национ Исаковичев је у време када се радња романа дешава, пред крај 18. века, изгубио све илузије да ће икада имати праведан третман у туђинском царству:

Та варош им је узимала, увек, и мита, и права, и крв, а није им ништа давала, сем обећања.

Пошто Павле, крај свег јахања у битке и ратове, на бојишта у иностранству, није познавао друге земље хришћанства, и Европе, он је, као и цела фамилија Исаковича, мислио да је Вијена Содома и Гомора.

А да је остала Европа просвећена и добра. (Црњански 1990: 211)

Докле год је Павле још у Бечу, где ужурбано и грозничаво ради на пребацивању целе своје фамилије из аустријске у војску руске царице Елисавете, простор коме стреми и који сања као огромни светли простор среће још увек је Русија, као и код Вука Исаковича, али Павлов сан о Русији се већ значајно разликује од Вуковог. Прво, Русија у његовој визији добија већ конкретне историјске, али и урбане контуре које се назиру у успутним описима руске престонице Санкт Петерсбурга. До тада су већ бројни земљаци доспели у руску царску војску, као генерал Шевич, и њихове приче о моћи и сјају руске царевине долазе и до официра који се спремају за одлазак из Аустрије. Други и важнији разлог што се визија Росије Вука Исаковича из прве књиге Сеоба толико разликује од слике Русије из Друге кюиге Сеоба, лежи у чињеници да сан који је надомак руке и који већ добија контуре стварног простора у конкретном историјском тренутку, престаје да буде сан и визија, дакле простор који гради само имагинација, самим тим оно 
губи одлике повлашћених и идеализованих простора среће. Вукова непрегледна и неограничена светла Росија, пространство зеленила или снега, постаје за Павла Исаковича царевина конкретних обриса о којој се причају различите приче од људи који долазе оданде, из тог стварносног простора, а и сам Павле коначно успева да оствари недосањани Вуков сан: после бројних препрека и тешкоћа, коначно долази у Русију, у област око Дњепра где ће се са фамилијом и населити. А судбина сваког реалног простора у поетском свету Милоша Црњанског јесте да се постепено претвори у место тескобе и муке, у место које губи смисао и самим тим поново захтева нови идеализовани простор среће. Тако се кроз време и простор стално помера у неизвесну даљину тај коначни, светли циљ који је заправо неухватљив, слично као и звездано небо изнад човека:

Увидео је какав ће крај сви они имати, и у философическом смислу, у Росији - крај који ће и он имати. Био је исти, који би и у Аустрији имали. Руски народ, Москву, Санкт-Петерсбург неће ни видети, нити познати. [...] А много су даље од своје Сервије, него што су од ње, у Срему, и на Моришу, били. Даће своју крв, па ће, у јесени, у степи, у Азову, нестати. (Црњански 1990: 739)

Ипак, као и сви јунаци поетског света Милоша Црњанског, ни Павле Исакович не одустаје од сна и упорне тежње за простором среће, за местом које ће постати остварење сна и осмислити сва мучна земаљска лутања, и његова и његовог национа. Идеализовани, небоземни простор и недостижни циљ његовог живота постаје тако град у даљини Санкт Петерсбург: „За време тог октобра он је, у Кијеву, стално, сањао, будан, како ће изгледати тај Санкт-Петерсбург, кад он, Исакович, тамо, стигне. [...] Петроград и царица били су, за те исељенике, надземаљско привиђење“ (Исто 1990: 762). 
Фокус се са непрегледног росијског царства, светлог, ванредног и лаког, недефинисаног и ничим земаљским ограниченог, пребацује на творевину људских руку, на царски град који су подигли Петар Велики и његови потомци, доводећи мајсторе „из далеких земаља, да њихове снове у камену остваре“. Ово остварење снова у камену, „варош коју је Росија дигла, као играчку, на мору, у леду“ је оно што је честњејшега Исаковича заувек приковало за сан о Санкт Петерсбургу: сазнање да се снови могу остварити и оваплотити и оставити као залог трајности онима који долазе, а још више као доказ да се живот може осмислити и изградити по свом сну и по својој вољи, ето, тако лако, како је и град на леду подигнут „као играчка“. За такав сан једино и вреди живети, а не за мучно тумарање и вечне сеобе, за „туђ рачун и по туђем налогу“, и управо за такав сан су живели јунаци поетског света Милоша Црњанског. Иако свестан да ће завршити живот негде на обалама Дњепра или у Азову, Паве Исакович стоји пред сликом Санкт Петерсбурга и пребацује се имагинацијом, као у сну, у тај чудесни град ка коме тежи као једином светлом циљу ради кога се може и мора живети. Та визија далеког града тако прераста у симбол свега чему су тежили његови преци, он сам и његов национ у сталним сеобама и мукама, кроз ратишта, блато, магле и ровове, у сталној неугаслој нади да ће коначно и они стићи у простор среће, у место које ће дати коначни смисао свим лутањима, у место пространства, лепоте, непрекинутих видика и светлости. Потрага за таквим местом никада не престаје:

Кроз ту слику, њему се, у даљини, причињаваху та кубета, која се плаве у провидној магли, а која су огромна - мора бити огромна - a, међутим, обичне замисли људске, остварење жеља царева росијских. У тој вароши 
он ће свој живот као утеху завршити. Она је ето, на води, а на води камен стоји. Кубета њена виде се, издалека, из веће даљине, него што човек може да замисли, и око да види. Плаве се и зову га, а знају да су они пошли, пре годину дана, а његов национ пре шездесет година, и ишли, ишли. Према тим кубетима, према тој води, према тој реци, према том мору. Према тој вароши, која је остварени сан, онога, на чију су реч, сви они пошли. (764-765)

Санкт Петерсбург прераста тако у завршној поетској визији Друге книге Сеоба у божански град, јер представља најважнији симбол свих тежњи јунака Црњанског, „остварени сан“, материјализовану имагинацију, место свеколиког добра, Нови Јерусалим свих Исаковича и њихових сународника, а град који постаје божански град самог песника и његове целокупне поетске визије, достигнути апсолут је Београд, град ка коме песник у емиграцији упире своје уморне и клонуле очи певајући Ламент над Београдом, једну од најзначајнијих посвета српском „вечитом граду“. Песник завичаја и неспутаних чистих предела природе, од поема Стражилово и Сербиа долази до града који постаје завршна визија свих његових лутања и чежњи за апсолутом. Те 1956. године, када је настала поема, песник је у емиграцији, а његов повратак у земљу је у потпуности неизвестан. Београд тако постаје идеализована слика у даљини, недостижна и сањана, у сталном измицању, у јасном и оштром контрасту са реалним простором у коме се песник налази и унутрашњим стањем јаке меланхолије и безнађа због неумитне старости и немоћи која га обузима. Када говоримо о поеми Ламент над Београдом, можемо у великој мери поистоветити појам лирског субјекта и самог песника, јер је то једини његов текст за који је сам Црњански нагласио да је аутобиографски: „Ламент над Београдом, међутим, то сам ја од речи до речи“ (Есеји и чланци II: 578). 
Бројне студије и чланци су написани о Ламенmу над Београдом, о његовој структури, контрастним строфама које се ни у једној тачки не додирују, или како истиче Хатиџа Крњевић, Црњански је у Ламенту „заувек располутио пролазност појединачног трајања од вечног природног и људског закона обнављања и самообнављања свега постојећег“ (Крњевић 1977). У непарним строфама у којима песник слика реалност лирског субјекта, његов стварносни простор и стање, наилазимо на његов потпуни суноврат, његова стварност налази се, како то Џаџић дефинише, у равни подземља, односно пада, на потпуно супротном полу од равни простора среће (Џаџић 1976). Он нема снаге ни да погледа у небо, као што је некада гледао песник суматраиста, његово потонуће је коначно и неповратно, уз стална понављања, ништа, ништа и ничево...

Међутим, у најдоследније изграђеном контрасту између стварног и сањаног у целокупном поетском свету Црњанског, који је једна од најизразитијих одлика слике света коју је изградио кроз своје дело, у парним строфама поеме израста бљештава узвишена слика апсолутне лепоте и добра, коначне утехе и симбола светлости и висина, слика вечног града у даљини, Београда. Песник само у наслову спомиње име града, а потом му се обраћа присно, свечано и егзалтирано, апострофирајући га са Ти, међутим: „растеш“, „шириш“, „стојиш“, „дишеш“, „крећеш“ и, коначно, „сјаш“. Град расте и дише и креће се, за разлику од лирског субјекта који непомичан чека крај свог живота, али последњом снагом проналази свој вечни и коначни простор среће, идеални град у даљини који живи и сја. И мада је тај град тако далек и различит у својој лепоти од гротескне стварности у којој је песник, он представља и његову коначну утеху, исто као и за Павла Исаковича Санкт 
Петерсбург, место његовог коначног одредишта, узвишени циљ коме се тежи до последњег даха: „А кад ми се глас, и очи, и дах, упокоје / Ти ћеш ме, знам, узети на крило своје“" (Песме: 265).

Име града се налази само у наслову, јер апсолут има само једно име, које се само једном и наводи. Град у Ламенту над Београдом постаје тако симбол и сублимација свих најузвишенијих визија које су водиле јунаке и лирске субјекте целокупног поетског света Милоша Црњанског у потрагу за идеалним, за апсолутом. Он прераста у симбол етеричних висина, који се постепено диже, а у завршним стиховима поеме и уздиже ка небу „Ти, међутим, дишеш, у ноћној тишини / до звезда, што казују пут Сунцу у твој сан“" (Песме: 267). Тако Београд постаје и небески град, симбол песниковог Новог Јерусалима, божанског савршеног града, оваплоћења свега доброг и вечног, снажан симбол и залог трајања. Истовремено, Београд прераста и у симбол светлости, блештаве и непролазне, и мада га у извесној мери можемо упоредити са бескрајним плавим кругом и звездом зорначом Вука Исаковича, он није непрегледно и нејасно пространство у даљини, већ град са конкретним обрисима и стварном историјом, слично као Санкт Петерсбург Павла Исаковича. У његовој поетској слици су и „Авала плава“, и „мрачни Калемегдан“ и Сава и Дунав.

Ипак, идеални град прераста и своје реалне оквире и његов сјај расте у мери у којој се успиње у висине, ка небу, ка Сунцу и звездама. Светлосни град трепери „кад овде звезде гасну“, „сјаји као ископан стари мач“, „блиста, као кроз сузе људски смех“, диже се „из јутра, сав зрацима обасут“, сија „кроз сан мој тавни“ (Песме: 265-269). Поред уздизања ка висинама, град се и шири, тако да је бескрајна ширина и висина којој стреми, завршна и тријумфална слика свих широких, бескрајних, 
уздигнутих и неспутаних простора среће ка којима су неуморно и до последњег удаха тежили сви јунаци прозних дела Милоша Црњанског, лирски субјекти песама, и на крају, и сам песник.

Како је Црњански кроз деценије стварања померао просторе среће од суматраистичких визија нетакнуте природе, преко стражиловских брда видљивих из Тоскане и неограниченог широког царства зелених пољана и снежних степа, ка граду као коначно пронађеном симболу трајања, оваплоћења људских снова и незалазне светлости? Ако поново погледамо у страсну и неугасиву тежњу јунака његовог поетског света ка удаљеним идеализованим просторима среће који су увек у супротности са реалним просторима кроз које се крећу, увиђамо да њихови снови не представљају никада само пуки ескапизам, већ конкретни реални циљ ка коме усмеравају своје животе, а кретање ка циљу, ма колико безнадежно деловало, једино је што даје смисао њиховом кретању кроз простор и време, и коначно њиховим животима. Град као творевина људских руку, простор који је човек издвојио из природе, оградио га и назидао по својој жељи и замисли, представља тако потврду оваплоћења људских снова и тежњи, конкретни и трајни доказ да се снови могу у „камен преточити“ и оставити да трају у вечности. Чежња за бесмртношћу пролазног и трошног људског бића бива на тај начин превладана, јер у камену остају изграђени и остварени снови поворке људи што су проминули кроз живот и нестали у небеском бескрају, али њихови снови остају вечни и настављају свој раст и ширење. Зато је и разумљиво да од младалачког порива ка ишчезнућу у пространству природе, који заправо представља пантеистичку чежњу и потребу за повратком у рај, стваралачка личност кроз непрестано ширење свести и сазнања о себи 
и свету, услед проласка кроз животне путеве и време, долази до сазнања да повратка у прапочетак нема и не може бити. Пут спасења своје судбине води нагоре и сталним успињањем, кроз стварање и учествовање у напору креације, преко бројних лутања, странпутица, успона и падова, али се све те сеобе завршавају и добијају смисао у вечном граду, месту апсолутног добра, симболу оваплоћења и трајности снова, бескрајног стваралачког ширења и залога вечности, ка којој сви људи теже, били тога свесни или не. Град је творевина која сведочи да је остављен непролазни траг у времену, траг који остаје у вечности, а у поетској визији Милоша Црњанског прераста своје земаљске, материјалне оквире и прераста у симбол људског стваралаштва, сваког уметничког дела које се гради и каменом али и речима, а пре свега сновима и визијом, од којих све почиње, али се не завршава никада, до у вечност.

\section{Извори и литература}

Ahmetagić, Jasmina. Pripovedač i priča. Leposavić: Institut za srpsku kulturu Priština/Leposavić, 2014. Štampano.

Башлар, Гастон. Ваздух и снови (оглед о имагинаиији креmaюа) (прев. М. Вуковић). Сремски Карловци, Нови Сад: Издавачка књижарница Зорана Стојановића, 2001. Штампано.

Башлар, Гастон. Вода и снови (оглед о имагинацији материје) (прев. М. Вуковић). Сремски Карловци, Нови Сад: Издавачка књижарница Зорана Стојановића, 1998. Штампано. Bašlar, Gaston. Poetika prostora (sa predgovorom S. Marića, prev. F. Filipović). Beograd: Kultura, 1969. Štampano.

Vladušić, Slobodan. Crnjanski, Megalopolis. Beograd: Službeni glasnik, 2012. Štampano.

Крњевић, Хатиџа. „Прамен дима са Итаке“. Кюижевна реч 91 (1977). Штампано. 
Милошевић, Никола. Роман Милоша Црюанског, проблем универзалног исказа. Београд: Српска књижевна задруга, 1970. Штампано.

Недић, Марко. Стилска преплитаға. Београд: Службени гласник, 2011. Штампано.

Петров, Александар. Поезија Црнанског и српско песништво. Београд: Signature, 1997. Штампано.

Радонић, Маја. „Престоница васељене и град памтивека (Цариград као митопоетски симбол у поезији Миодрага Павловића)“. Зборник радова са међународне научне конферениије „Сан о граду“ Одјељена за книжевност Андрићевог института одржаног 2018. у Вишеграду. Александра Вранеш (ур.). Андрићград - Вишеград: Андрићев институт, 2018: 186-187. Штампано.

Црњански, Милош. Есеји и чланиц II. Београд, Lausanne: Задужбина Милоша Црњанског, БИГЗ, СК3, L’Age d'Homme, 1999. Штампано.

Crnjanski, Miloš. Kod Hyperborejaca, prva knjiga. Beograd: Nolit, 1983. Štampano.

Crnjanski, Miloš. Kod Hyperborejaca, druga knjiga. Beograd: Nolit, 1983. Štampano.

Crnjanski, Miloš. Pesme sa Antologijom kineske lirike i Pesmama starog Japana. Beograd: Nolit, 1983. Štampano.

Црњански, Милош. Путописи II: Путевима разним, Дела Милоша Црњанског IX, књига 20, Београд: Задужбина Милоша Црњанског, 1995. Штампано.

Crnjanski, Miloš. Roman o Londonu, prva knjiga. Beograd: Nolit, 1983. Štampano.

Crnjanski, Miloš. Roman o Londonu, druga knjiga. Beograd: Nolit, 1983. Štampano.

Црњански, Милош. Сеобе /Друга књига Сеоба.Београд: Задужбина Милоша Црњанског, 1990. Штампано.

Џаџић, Петар. Простори среће у делу Милоша Црғанског. Београд: Нолит, 1976. Штампано.

Џаџић, Петар. „Утопијско у делу Милоша Црњанског“. М. Шутић и М. Грујић (прир.). Милош Црнански: теоријско-естетички приступ књижевном делу. Београд: Институт за књижевност и уметност, 1996. 51-56. Штампано. 
Maja Radonić

\section{A DREAM ABOUT CITY IN THE POETIC WORLD MILOŠ CRNJANSKI}

Starting from the distinctive peculiarity of Miloš Crnjanski's poetics, it is the constant tendency of the hero of his prose and lyrical subject in poetry to move with the power of imagination from the real space in which they are, and which signifies the space of anxiety, restraint and meaninglessness, into idealized spaces of happiness, which are As a rule, far and unattainable, even though these are real remote spaces, we pointed out through work two ideal cities that in the later parts of Crnjanski became visions of the ultimate goal and the ideal destination of destiny. From the space of fortune sought by the heroes of his earlier prose and the lyrical subjects of the poem Stražilovo and Serbia, which, as a rule, represented the unearthly landscapes of the far idyllic spaces of nature and the heavenly expanse, Crnjanski moved the spaces of happiness from the realms of nature in the Second Book of Movement and Poem Lament over Belgrade towards two cities: St. Petersburg in the vision of Pavel Isakovich and Belgrade in the poem Lament over Belgrade. Thus, these two cities also became symbols of the possibility of the realization of man's dreams in stone, a pledge of permanence and eternity, a symbol of the attainment of everything bright, impassable and unlimited, which is persistent and passionate, strived processional of the hero of the poetic world of Miloš Crnjanski. 